\title{
Purifikasi Kolagenase dari Usus Bandeng (Channos channos, Forskal)
}

\section{Collagenase Purification of Intestines of Milkfish (Chanos chanos, Forskal)}

Tatty Yuniarti ${ }^{1}$, Tati Nurhayati ${ }^{2 *}$, dan Agoes Mardiono Jacoeb ${ }^{2}$

${ }^{1}$ Jurusan Penyuluhan Perikanan, Sekolah Tinggi Perikanan, Kementrian Kelautan dan Perikanan Jl.Cikaret No.2 PO BOX 155 Bogor

${ }^{2}$ Departemen Teknologi Hasil Perairan, Institut Pertanian Bogor

Email: tatty_yuni@yahoo.co.id *Penulis untuk korespondensi

\begin{abstract}
Collagenase was purified from intestines of milkfish (Chanos chanos, Forskal) by extraction, ammonium precipitation, ion exchange chromatography on DEAE Sephadex A-50 and gel filtration on a Sephadex G-100 column. The purification and yields were 114.731 fold and $1.26 \%$ when compared to those in the starting-crude extract. The molecular mass of milkfish serine collagenase was estimated to be $14.63 \mathrm{kDa}$ and $27.46 \mathrm{kDa}$.
\end{abstract}

Key words: Collagenase, purification, intestines, milkfish

\begin{abstract}
Abstrak
Enzim kolagenase telah dapat dimurnikan dari usus ikan bandeng (Chanos chanos, Forskal), menggunakan ekstraksi, pengendapan menggunakan ammonium sulfat, kromatografi pertukaran ion menggunakan DEAE Sephadex A-50 dan gel filtrasi menggunakan kolom Sephadex G 100. Hasil penelitian menunjukkan kelipatan pemurnian sebesar 114,731 fold, dan yields sebesar $1,26 \%$ dari ekstrak kasarnya. Berat molekul kolagenase jenis serin ini adalah 14,63 kDa dan 27,46 kDa.
\end{abstract}

Kata kunci: Enzim kolagenase, pemurnian, usus, ikan bandeng

Diterima: 27 April 2010, disetujui: 14 Agustus 2010

\section{Pendahuluan}

Enzim-enzim proteolisis bekerja dengan cara menghidrolisis protein pada daging ikan. Enzim-enzim tersebut antara lain kolagenase, katepsin dan kalpain. Aktivitas kolagenase menyebabkan terpisahnya jaringan ikat daging ikan (gaping) (Hultman dan Rustrad, 2004; Loli et al., 2006). Enzim kolagenase memisahkan serat-serat daging ikan, yang terdapat jaringan kolagen pada serat ikan yang dihubungkan oleh myocotoma. Akibatnya tekstur ikan menjadi lembek dan protein daging ikan terpecah menjadi peptida-peptida sederhana. Peptida ini merupakan substrat bagi bakteri, sehingga setelah autolisis, peranan mikroorganisme penyebab kebusukan menjadi dominan.

Bagian organ dalam ikan bandeng diketahui mempunyai aktivitas kolagenase tertinggi pada fase post rigor (Fentiana, 2009). Bagian organ dalam bandeng yang mempunyai aktivitas kolagenase tertinggi terdapat pada organ usus (Yuniarti et al., 2009). Selain dapat menyebabkan kemunduran mutu ikan, sebagai produk bioteknologi, kolagenase dapat digunakan sebagai alternatif sumber enzim baru, sebab sumber-sumber enzim baru masih diperlukan (BPPT, 2003). Kolagenase telah digunakan dalam perbaikan radang pada jaringan, transplantasi klinis, fungsi seluler dalam penggumpalan darah, fibrinolisis dan fertilisasi (Simpson, 2000) dan mempercepat proses penyembuhan luka (Rilley dan Herman, 2005). Kolagenase dari hepatopankreas kepiting telah digunakan untuk deskinning pada cumicumi (Lopez dan Carreno, 2000). Mengingat peranan kolagenase tersebut, maka dilakukan purifikasi dan karakterisasi kolagenase dari organ dalam ikan bandeng.

Penelitian ini bertujuan mendapatkan kolagenase yang murni dan menentukan berat molekul kolagenase yang diperoleh. Penelitian ini bermanfaat untuk mendapatkan informasi metode purifikasi kolagenase sehingga dapat 
memanfaatkan organ dalam terutama usus ikan bandeng sebagai salah satu alternatif sumber kolagenase.

\section{Metode Penelitian}

Ikan bandeng diperoleh dari tambak di desa Dadap, Tangerang. Selanjutnya, organ dalamnya dipreparasi, untuk diambil bagian ususnya. Usus tersebut kemudian diekstraksi menggunakan metode Kim et al., (2002), ditambah dengan buffer Tris-HCl (Applicchem) pada $\mathrm{pH}$ 8,0 dan dihomogenisasi menggunakan homogenizer (Nissei AM-3). Homogenat disentrifugasi menggunakan sentrifuse dingin (Sorvall) dengan kecepatan 7000xg selama 20 menit pada suhu $4^{\circ} \mathrm{C}$. Supernatan ditambah dengan $20 \mathrm{mM}$ Tris- $\mathrm{HCl} \mathrm{pH}$ 8,0.

Ekstrak kolagenase kasar diendapkan menggunakan ammonium sulfat padat dengan tingkat kejenuhan $70 \%(w / v)$. Hasil pengendapan terbaik didialisis menggunakan kantong berukuran molecular weight cut off (MWCO) 8 $\mathrm{kDa}$ (Sigma) selama 6 jam. Purifikasi kolagenase menggunakan kolom kromatogafi penukar ion $(1,5 \times 30 \mathrm{~cm})$, media pendukung DEAE-SephadexA-50 (Sigma) yang diekuilibrasi menggunakan buffer $20 \mathrm{mM}$ Tris- $\mathrm{HCl} \mathrm{pH} 8,0$. Fraksi yang mempunyai aktivitas kolagenase tertinggi, dimurnikan lagi menggunakan kromatografi gel filtrasi matriks Sephadex G-100 (Sigma). Fraksi-fraksi kolagenase yang dihasilkan diuji aktivitas kolagenase serta absorban proteinnya pada $\lambda 220 \mathrm{~nm}$.

Berat molekul ditentukan menggunakan gel elektroforesis SDS-PAGE, menggunakan marker (Pharmacia), yaitu phosphorilase b (97 $\mathrm{kDa}), \mathrm{BSA}$ (bovine serum albumin) $(66,0 \mathrm{kDa})$, ovalbumin $(45 \mathrm{kDa})$, carbonic anhydrous $(29,0$ $\mathrm{kDa})$, tripsin inhibitor $(20,1 \mathrm{kDa})$ dan $\alpha$ laktalbumin $(14,4 \mathrm{kDa})$ dengan penanda warna pita protein, yaitu $\mathrm{AgNO}_{3}$ (Merck) 0,1 M. Analisis meliputi uji aktivitas kolagenase (Moore dan Stein, 1954 diacu dalam Kim et al., 2002) dan analisis protein Bradford (1976). Satu unit aktivitas kolagenase didefinisikan sebagai jumlah enzim yang menyebabkan perubahan 1 $\mu$ mol substrat per menit pada suhu $37^{\circ} \mathrm{C}$ dan $\mathrm{pH}$ 8,0 .

\section{Hasil dan Pembahasan}

Hasil uji aktivitas kolagenase terhadap ekstrak kasar kolagenase dari usus ikan bandeng menghasilkan aktivitas sebesar 0,141 Unit/ml. Kolagenase diproduksi oleh sel-sel jenis sel stromal, sel ephitel, makrofagus dan leukosit (Strenlicht dan Werb, 2001). Usus merupakan organ dalam pencernaan ikan yang tersusun dari sel-sel epitel (Khojasteh et al., 2009). Selain pada usus, kolagenase terdapat pada organ dalam ikan tuna (Thunnus sp.) (Kumaila, 2008); hepatopankreas kepiting raja (Paralithodes camtschaticus) (Rudenskaya et al., 2004).

Hasil uji aktivitas terhadap endapan hasil pengendapan dengan penambahan $70 \%(\mathrm{w} / \mathrm{v})$ tingkat kejenuhan $\mathrm{NH}_{4}\left(\mathrm{SO}_{4}\right)_{2}$, yaitu sebesar 0,496 Unit $/ \mathrm{ml}$ dengan konsentrasi protein sebesar $1,185 \mathrm{mg} / \mathrm{ml}$. Ada beberapa bahan yang dapat digunakan untuk mengendapkan enzim, seperti aseton dingin dan ammonium sulfat (Byun et al., 2002 dan Park et al., 2002). Ammonium sulfat dipilih karena sifatnya yang mudah larut, murah dan umumnya tidak mempengaruhi struktur protein pada konsentrasi tertentu (Beynon dan Bond, 2000). Aktivitas kolagenase pada konsentrasi ammonium sulfat tingkat kejenuhan $80 \%$ menurun. Penurunan ini disebabkan oleh ammonium sulfat tidak bersifat buffer dan dapat membebaskan ammonia, sehingga memungkinkan terjadinya kenaikan $\mathrm{pH}$ (Boyer, 1993).

Dialisis menggunakan kantong dialisis berukuran $8 \mathrm{kDa}$ MWCO selama 6 jam, menghasilkan aktivitas sebesar $0,451 \mathrm{U} / \mathrm{ml}$. Dialisis dilakukan untuk mengurangi kadar garam (desalting) yang tersisa dari pengendapan menggunakan garam $\mathrm{NH}_{4}\left(\mathrm{SO}_{4}\right)_{2}$. Perbedaan tekanan osmosis dari larutan buffer yang mengandung konsentrasi garam rendah (hipotonik) dengan larutan enzim dalam kantong dialisis yang mengandung garam tinggi (hipertonik) menyebabkan garam terdifusi keluar membran kantung dialisis, biasanya bersifat semipermeabel. Dialisis mengeluarkan protein dengan ukuran yang lebih kecil dari ukuran poripori kantung dialisis. Dialisis yang dilakukan dengan mengganti buffer beberapa kali akan meningkatkan kemurnian enzim. Lama waktu diffusi dan ukuran kantong dialisis serta 
konsentrasi buffer menentukan hasil dialisis (Bollag dan Edelstein, 1991).

Pemisahan menggunakan kolom kromatografi penukar ion menghasilkan fraksi sebanyak 62. Terdapat tiga puncak aktivitas kolagenase. Aktivitas kolagenase tertinggi terdapat pada fraksi yang ke-11 sebesar 0,658 U/menit dengan absorban 0,352. Aktivitas kolagenase tertinggi terdapat pada fraksi-fraksi di awal pemisahan, sehingga diduga muatannya tidak terlalu kuat. Kromatografi penukar ion merupakan teknik pemisahan molekul-molekul berdasarkan perbedaan jenis muatan adsorben dan komponen suatu sampel. Media kromatografi sebagai fase diam, mengandung resin bermuatan (+) di dalam kolom dialiri buffer, molekul-molekul sampel yang bermuatan berlawanan berikatan dengan resin. Ketika dielusi dengan larutan yang mempunyai kekuatan ionik tertentu (fase bergerak) yaitu $\mathrm{NaCl}$, larutan tersebut akan mengganti sampel yang bermuatan untuk berikatan dengan media (fase diam) (Boyer, 1993). Grafik hasil kromatogafi penukar ion disaji pada Gambar 1.

Purifikasi kolagenase selanjutnya adalah kromatografi gel filtrasi. Sebanyak 60 fraksi dihasilkan dari pemisahan ini. Aktivitas kolagenase tertinggi terdapat pada fraksi yang ke-7 sebesar 0,274 U/menit dengan absorban 0,127. Gel Sephadex G-100 dapat digunakan untuk memisahkan kolagenase dengan pengotor lainnya. Grafik hasil kromatografi gel filtrasi disajikan pada Gambar 2. Media yang digunakan dalam memisahkan molekul-molekul yang berbeda ukurannya pada kromatografi gel filtrasi adalah dekstran yang telah mengalami reaksi cross linkage dengan bantuan epikhlorhidrin. Hasilnya adalah dekstran yang tidak larut air, tetapi dapat menyerap air dalam molekulnya sendiri. Kode G-100 menunjukkan besarnya pengembangan 100 kali setelah direndam dalam air. Adapun kisaran fraksinansi Sephadex G-100 adalah memisahkan molekul dengan berat 4000-150000 kDa (Harris dan Angal, 1989).

Tahapan proses pemurnian telah berjalan dengan baik hal ini dapat dilihat dengan peningkatan kelipatan pemurniannya. Hasil pemurnian disajikan pada Tabel 1. Kelipatan pemurnian ini lebih tinggi dari pemurnian kolagenase dari ikan filefish (Novodon modestrus) yaitu sebesar 92,4 (Kim et al., 2002) dan udang (Pandalus eous) yaitu sebesar 37,4 (Aoki et al., 2003).

Hasil elektroforesis memperlihatkan bahwa terdapat dua band (pita) molekul dari fraksi yang ke-7 hasil pemurnian kromatografi gel. Berat molekul kolagenase tersebut adalah 27,61 kDa dan 14,36 kDa. Berdasarkan fungsi fisiologisnya, kolagenase digolongkan menjadi dua tipe, yaitu serin kolagenase dan metallokolagenase. Berat molekul kolagenase dari ikan bandeng ini hampir sama dengan berat molekul serin kolagenase dari ikan makarel (Scromber japanicus) yaitu 14,8 kDa (Park et al., 2002) dan ikan filefish (Novodon modestrus) yaitu $27 \mathrm{kDa}$ (Kim et al., 2002). Hasil elektroforesis disajikan pada Gambar 3.

Kolagenase jenis mettalokolagenase mempunyai berat molekul yang bervariasi dari 30 hingga $150 \mathrm{kDa}$. Kolagenase dari daging ikan Pasific rockfish (Sebastes sp.) menyerupai kolagenase yang ditemukan pada hewan mamalia, mempunyai berat molekul 47 dan 95 $\mathrm{kDa}$ (Brocho dan Haard, 1995). Berat molekul metallokolagenase dari Clostridium perfringens 120 kDa (Matsusita et al., 1994), Photorhabdus luminescens $74 \mathrm{kDa}$ (Marokhazi et al., 2004), dan Streptomyces parvulus $52 \mathrm{kDa}$ (Sakurai et al., 2009).

Tabel 1. Hasil pemurnian kolagenase.

\begin{tabular}{lcccccccc}
\hline \hline \multicolumn{1}{c}{ Tahapan } & $\begin{array}{c}\text { Volume } \\
(\mathbf{m l})\end{array}$ & $\begin{array}{c}\text { Aktivitas } \\
\text { Enzim } \\
\text { Unit/ml }\end{array}$ & $\begin{array}{c}\text { Aktivitas } \\
(\mathbf{U})\end{array}$ & $\begin{array}{c}\text { Konsentrasi } \\
\text { Protein } \\
(\mathbf{m g} / \mathbf{m l})\end{array}$ & $\begin{array}{c}\text { Protein } \\
(\mathbf{m g})\end{array}$ & $\begin{array}{c}\text { Aktivitas } \\
\text { Spesifik } \\
\text { U/mg }\end{array}$ & $\begin{array}{c}\text { Derajat } \\
\text { Kemurnian }\end{array}$ & Yield \\
\hline \hline Ekstraksi & 450 & 0,141 & 63 & 0,785 & 353,25 & 0,178 & 1,00 & 100,00 \\
Hasil pengendapan 70\% & 45 & 0,496 & 2,32 & 1,185 & 53,325 & 0,419 & 2,347 & 35,42 \\
ZA & & & & 1,020 & 23,260 & 0,388 & 2,484 & 14,32 \\
Dialisis & 20 & 0,451 & 9,020 & 0,095 & 0,190 & 6,916 & 38,778 & 2,08 \\
DEAE Sephadex A-50 & 5 & 0,657 & 1,314 & 0,095 \\
Sephadex G-100 & 5 & 0,133 & 0,798 & 0,0065 & 0,039 & 20,462 & 114,731 & 1,26 \\
\hline \hline
\end{tabular}




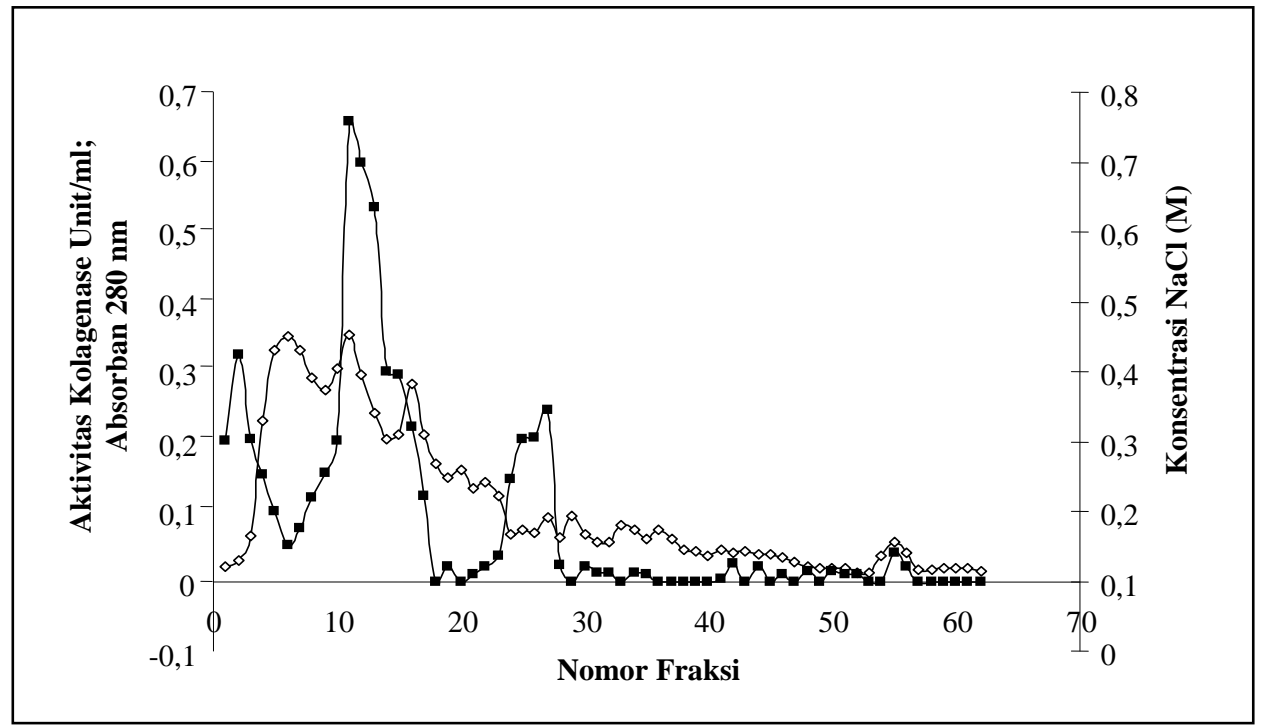

Gambar 1. Hasil kromatografi penukar ion. $(\diamond)$ absorban pada $280 \mathrm{~nm},(\mathbf{\bullet})$ aktivitas kolagenase.

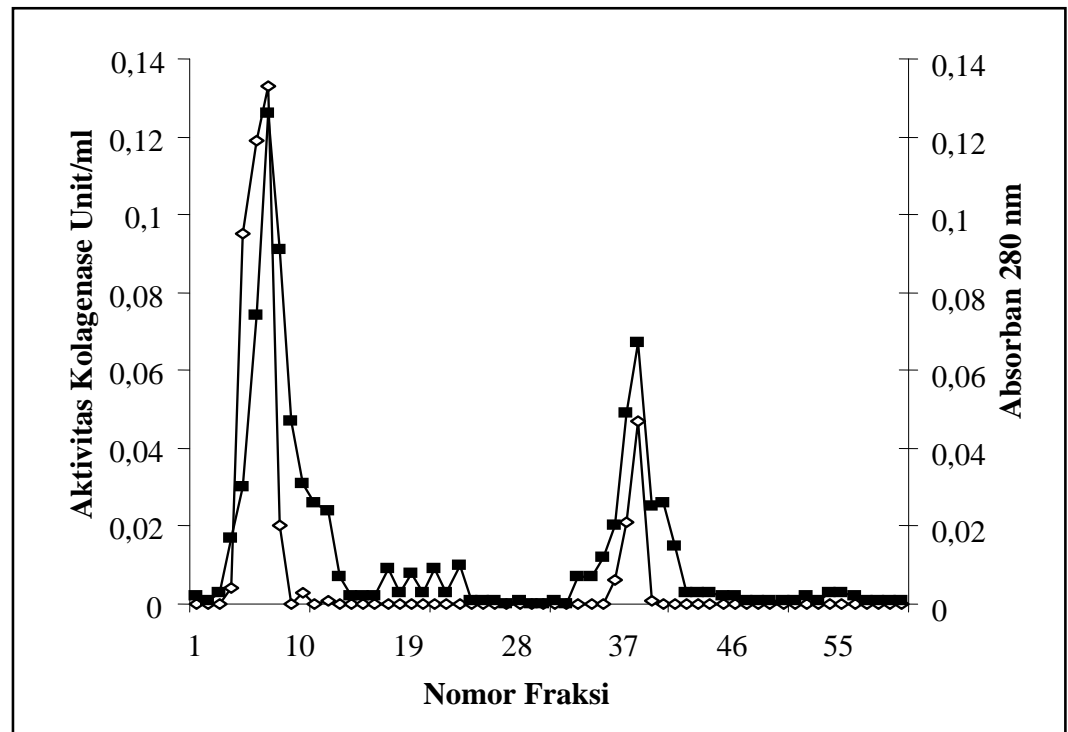

Gambar 2. Hasil kromatografi gel filtrasi.( () aktivitas kolagenase, (ש) absorban pada $280 \mathrm{~nm}$.

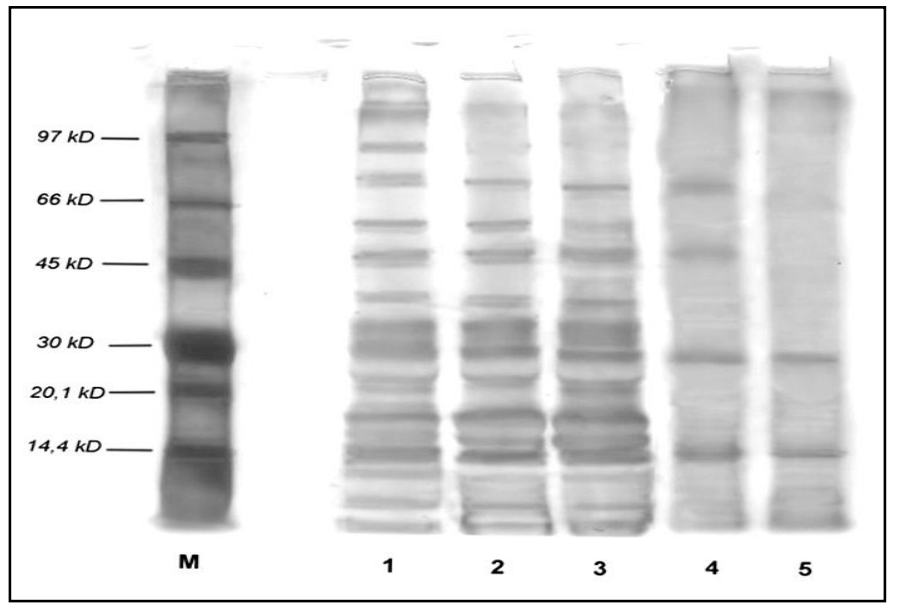

Gambar 3. Hasil elektroforesis: (M) Marker, (1) ekstrak kasar, (2) hasil pengendapan ammonium sulfat, (3) hasil dialisis, (4) penukar ion, (5) filtrasi gel. 


\section{Simpulan dan Saran}

\section{Simpulan}

Enzim kolagenase dari usus ikan bandeng telah dapat dimurnikan dengan baik, dengan kelipatan pemurnian yang tinggi. Kolagenase ini tergolong dalam enzim yang bekerja dengan optimal pada $\mathrm{pH}$ netral cenderung basa (alkalin proteinase) adalah jenis serin protease.

\section{Saran}

Untuk penelitian selanjutnya adalah penggunaan metode yang lain untuk pemurnian kolagenase, agar dapat dihasilkan kolagenase lebih murni.

\section{Ucapan Terima Kasih}

Penelitian ini sebagian dibiayai oleh Dana Hibah Bersaing Batch DP2M-Ditjen DiktiDEPDIKNAS Tahun 2009 atas nama Dr. Tati Nurhayati, S.Pi, M.Si.

\section{Daftar Pustaka}

Aoki, H., Ahsan, M.N., Matsuo, K., Hagiwara, T. dan Watanabe, S. 2003. Purification and Characterization of Collagenolytic Proteases from The Hepatopancreas of Northern Shrimp (Pandalus eous). J. Agric Food Chem., 51: 777-83.

[BPPT] Badan Pengkajian dan Penerapan Teknologi. 2003. Seminar Industri Enzim dan Bioteknologi. Jakarta: Humas BPPT. http://www.bppt.go.id/ index.php? option $=$ com_ content $\&$ task $=$ view $\&$ $\mathrm{id}=1549 \&$ Itemid $=30$.

Beynon, R.J. dan Bond, J.S. 2001. Proteolisis Enzymes: a Practical Approach. New York: Oxford University Press.

Bollag, D.M. dan Edelstein, S.J. 1991. Protein Methods. New York: A Jhon Willey and Sons Inc. Publication.

Boyer, R.F. 1993. Modern Experimental Biochemistry. Edisi kedua. Redwoodcity. California: The Benjamin/Cummings Publishing Co. Inc.

Brocho, G.E. dan Haard, N.F. 1995. Identification of Two Matrix Metalloproteinases in the Skeletal Muscle of Pacific Rockfish (Sebastes sp.). J. Food Biochem., 19: 299-319.
Byun, H.G., Park, J.P., Sung, N.I. dan Kim, S.K. 2002. Purification and Characterization of a Serine Proteinase from The Tuna Piloric Caeca. J. Food Biochem., 26: 479-494.

Fentiana, N. 2009. Pengaruh Enzim Protease Jeroan Bandeng (Channos channos Forskal) pada Proses Kemunduran Mutu. Skripsi. Bogor: Departemen Teknologi Hasil Perairan. IPB.

Harris, E.L.V. dan Angal, S. 1989. Protein Purification Methods. A Practical Approach. Oxford New York Tokyo: IRL Press.

Hultmann, L. dan Rustad, T. 2004. Iced Storage of Atlantic Salmon (Salmo salar) Effects on Endogeneus Enzymes and Their Impact on Muscle Proteins and Texture. J. Food Chemistry., 87: 31-41.

Kim, S.K., Park, P.J., Kim, J.B. dan Sahidi, F. 2002. Purification and Characterization of a Collagenolytic Protease from Filefish (Novodon modestrus). J. Biochem Mol Bio., 35: 165-171.

Khojasteh, S.M.N., Seikhzadeh, F., Mohammadnejad, D. dan Azami, A. 2009. Histological, histochemical and ultrastructural study of the intestine of rainbow trout (Oncorhynchus mykiss). World Appl Sci J., 6 (11): 1525-1531.

Kumaila, R. 2008. Ekstraksi Karakterisasi dan Aplikasi Enzim Kolagenase dari Organ Dalam Ikan Tuna (Thunnus sp.) Skripsi. Bogor: Program Studi Teknologi Hasil Perikanan. Fakultas Perikanan dan Ilmu Kelautan, IPB.

Loli, N., Lily, N. dan Meryandini, A. 2006. Karakterisasi Protease Ekstraseluler Clostridium spp. T11-3. Biota, XI (1): 47-51.

Lopez, M.D. dan Carreno, L.G. 2000. Applications of Fish and Shellfish Enzymes in Food and Feed Products. In: Haard, N.F. \& Simpson, B.K. (Eds.). Seafood Enzymes Utilization and Influence on Postharvest Seafood Quality. New York: Marcel Dekker. Inc.

Matsusita, O., Yoshihara, K., Katayama, S., Minami, J. dan Okabe, A. 1994. Purification and Characterization of a Clostridium perfringens120-Kilodalton Collagenase and Nucleotide Sequence of the Corresponding Gene. J. of Bacteriology, 149-156.

Marokhazi, J., K'ochzan, G., Hudecz, F., Graf, L., Fodor, A. dan Veneki, I. 2004. Enzymic characterization with progress curve analysis of a collagen peptidase from an enthomopathogenic bacterium, Photorhabdus luminescens. Biochem. J., 379: 633-640.

Park, P.J., Lee, S.H., Byun, H.G., Kim, S.H. dan Kim, S.K. 2002. Purification and Characterization of a Collagenase from The Mackarel, Scomber japonicus. J. Biochem. Mol. Bio., 35: 576-582. 


\section{Purifikasi Kolagenase dari Usus Bandeng}

Rilley, K.M. dan Herman, I.M. 2005. Collagenase Promotes the Celuller Responses to Injury and Wound Healing In Vivo. J. Burns and Wounds., 4: 112-124.

Rudenskaya, G.N., Kislitsin, Y.A. dan Rebrikov, D.V. 2004. Collagenolityc Serine Protease PC and Trypsin PC from King Crab Paralithodes camtschaticus: cDNA Cloning and Primary Structure of the Enzymes. BMC Structural Biology, 4: 2 .

Sakurai, Y., Inoue, H., Nishii, W., Takashi, T., Iino, Y., Yamamoto, M. dan Takashi, K. 2009. Purification and Characterization of Major Collagenase from Streptomyces parvulus. Biosci. Biothechnol. Biochem., 73 (1): 21-28.
Simpson, B.K. 2000. Digestives Proteinases from Marine Animals. In: Haard, N.F. dan Simpson, B.K. (Eds.). Seafood Enzymes Utilization and Influence on Postharvest Seafood Quality. New York: Marcel Dekker. Inc.

Strenlicht, Md. dan Werb, Z. 2001. How Matrixmetalloproteinases Regulate Cell behavior. Annu. Rev. Cell Dev. Biol., 17: 463-516.

Yuniarti, T., Nurhayati, T. dan Jacoeb, A.M. 2009. Ekstraksi dan Karakterisasi Kolagenase dari Organ dalam Bandeng (Chanos chanos, Forskal). Prosiding Seminar BRKP. 23 Agustus 2009. 